\title{
Identification of Beef Fat through Image Processing and Biospeckle
}

\section{Bárbara Rossi Corrales*, Juliana Aparecida Fracarolli}

\begin{abstract}
Meat processing, especially beef, in slaugherhouses have been an evolving process, visible mainly through the mechanization of the beef cuts. The identification of the fat percentage present in a piece of beef is commercially important, determining the price of the end product. Optical techniques can identify fat in beef automatically. A technique which has been widely used in the analysis of fruit and seeds, with adaptations, named Biospeckle allowed to evaluate levels of biological activities occurring in different beef tissues. In this paper, the Moment of Inertia (MI) was calculated and Activity Maps were obtained through the LASCA method. A third method, Image Processing, was also used. With all those data, it was possible to obtain an algorithm capable of differentiating beef adipose tissue from connective and muscle tissues.
\end{abstract}

\section{Key words:}

Muscle tissue, outside flat, lipidic tissue.

\section{Introduction}

The Biospeckle and Image Processing techniques will allow for the obtaining of information for the development of methods which will differentiate adipose tissues from muscle tissues in a piece of beef. With the proper adaptations, Biospeckle will make it possible to evaluate levels of biological activities occurring on the surface of different types of tissues present in a piece of beef. The moment of inertia and the production of the biological activity map through the LASCA method constitute ways of obtaining information through Biospeckle.

This paper aims for the application of optical techniques for the food industry, principally, starting with the beef sector, identifying lipidic tissues and muscle tissues. Thus, through optical techniques it will be possible in future studies that beef be automatically processed, through robotic cutting equipment connected to computers which use machine vision, through Biospeckle.

\section{Results and Discussion}

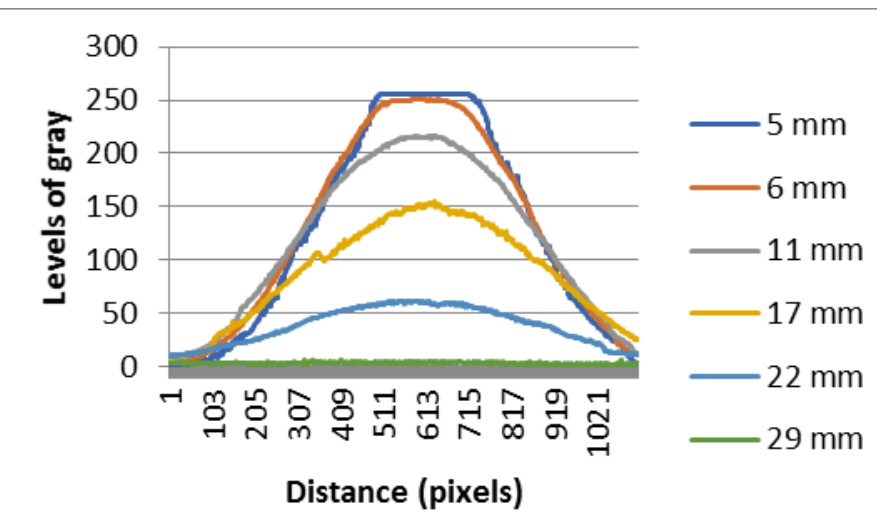

Figure 1: Transmission of the red laser in the samples of muscle tissues

Table 1 - Result of the Tukey test for the green laser

\begin{tabular}{ll}
\hline & Ml Means from Test \\
\hline Fat & $2.130080 \mathrm{a} 1$ \\
Muscle & $2.641180 \mathrm{a} 1$ \\
\hline
\end{tabular}

Table 2 - Tukey test for the red laser

\begin{tabular}{ll}
\hline & Ml Means from Test \\
\hline Fat & 0.113855 a1 \\
Muscle & $0.264000 \mathrm{a} 2$ \\
\hline
\end{tabular}
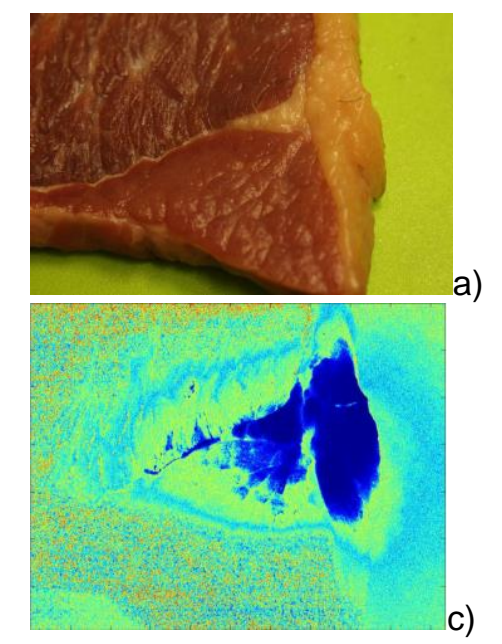

\section{Conclusions}

For the Biospeckle, the green laser presented lower penetration and it also did not present statistical differentiation through the $\mathrm{MI}$ method between muscle tissue and lipidic tissue. However, for the LASCA map, the green laser resulted in clearer, well-delimited biological activity maps, it being possible to visualize the color difference in area around both tissues when in the same sample.

\section{Acknowledgement}

I acknowledge professor Juliana Fracarrolli, Antonio Carlos Costa from the IFGW teaching laboratory and Rosa Helena Aguiar from Feagri's Post-Harvest Technology Laboratory.

Moreira, M. F. B. et al. Caracterização da Transmissão da luz laser em semente de feijão (Phaseolus vulgaris L.). Revista Brasileira de

Produtos Agroindustriais, v. 4, n. 2, p. 119-125, 2002. 